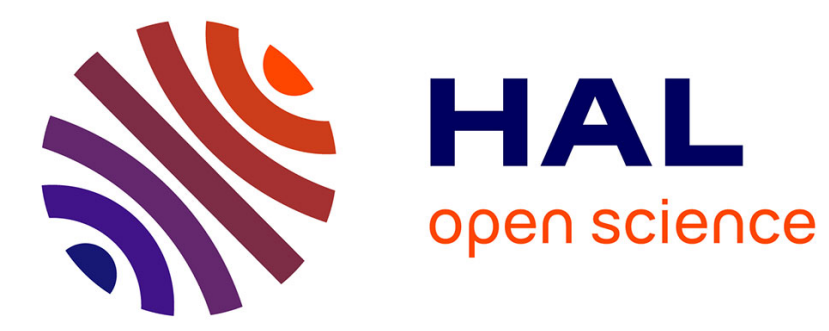

\title{
Total Synthesis of the Marine Macrolide Amphidinolide F
}

\author{
Laurent Ferrié, Johan Fenneteau, Bruno Figadère
}

\section{To cite this version:}

Laurent Ferrié, Johan Fenneteau, Bruno Figadère. Total Synthesis of the Marine Macrolide Amphidinolide F. Organic Letters, 2018, 20 (11), pp.3192-3196. 10.1021/acs.orglett.8b01020 . hal02356320v2

\section{HAL Id: hal-02356320 \\ https://hal.science/hal-02356320v2}

Submitted on 12 Nov 2019

HAL is a multi-disciplinary open access archive for the deposit and dissemination of scientific research documents, whether they are published or not. The documents may come from teaching and research institutions in France or abroad, or from public or private research centers.
L'archive ouverte pluridisciplinaire HAL, est destinée au dépôt et à la diffusion de documents scientifiques de niveau recherche, publiés ou non, émanant des établissements d'enseignement et de recherche français ou étrangers, des laboratoires publics ou privés. 


\title{
Total Synthesis of the Marine Macrolide Amphidinolide F.
}

\author{
Laurent Ferrié,* Johan Fenneteau and Bruno Figadère* \\ BioCIS, Univ. Paris-Sud, CNRS, Université Paris-Saclay, 92290, Châtenay-Malabry, France.
}

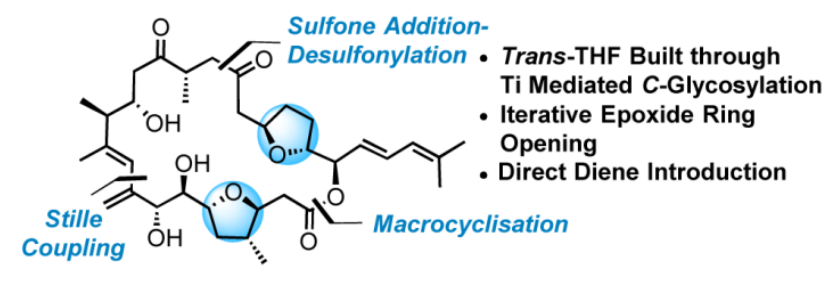

ABSTRACT: A new and efficient convergent approach toward the synthesis of amphidinolide F is described through the assembly of three fragments. The two trans-tetrahydrofurans were built by a diastereoselective $C$-glycosylation with titanium enolate of bulky $\mathrm{N}$-acetyl oxazolidinethiones. The side-chain was inserted by a Liebeskind-Srogl cross coupling reaction. A sulfone condensation/ desulfonylation sequence, a Stille cross-coupling, and a macrolactonisation were applied to connect the fragments.

Amphidinolides are part of a large family of macrolides containing more than 30 members, all being isolated from different strains or species of the dinoflagellate amphidinium. ${ }^{1}$ Amphidinolides $\mathrm{F}(\mathbf{1}),{ }^{2} \mathrm{C}(\mathbf{2}),{ }^{3} \mathrm{C} 2(\mathbf{3}),{ }^{4}$ and $\mathrm{C} 3{ }^{5}(\mathbf{4})$ particularly drawn our attention due to the presence of two transtetrahydrofurans, 11 to 12 stereogenic centers, and two dieneframeworks at $\mathrm{C} 9-\mathrm{C} 11$ and at $\mathrm{C} 25-\mathrm{C} 28$, which make these molecules unique in their family. These marine natural products are very similar in terms of structure, exhibiting the same macrolactone. In consequence, the stereochemical assignment of amphidinolide F (1) was originally deduced from its analogy with amphidinolide C (2). The differences rely only on the side chain, amphidinolide F (1) being six carbons shorter. On the other hand amphidinolide C (2) contains one more stereogenic center at C29, and natural derivatives C2 (3) and C3 (4) show differences only at this position, the hydroxyl group being acylated for $\mathbf{3}$ while oxidized for $\mathbf{4}$ (Figure 1).

These amphidinolides show significant cytotoxic activities against some cancer cell lines. Amphidinolide C (2) is particularly active on murine lymphoma L1210 and human epidermoid carcinoma $\mathrm{KB}$ cells lines $\left(\mathrm{IC}_{50}\right.$ of 5.8 and $4.6 \mathrm{ng} / \mathrm{mL}$ respectively), ${ }^{3}$ while a reduced cytotoxicity is observed for $\mathbf{1}$ $(1.5$ and $3.2 \mu \mathrm{g} / \mathrm{mL}),{ }^{2} \mathbf{3}(0.8$ and $3.0 \mu \mathrm{g} / \mathrm{mL}),{ }^{4} \mathbf{4}(7.6$ and 10.0 $\mu \mathrm{g} / \mathrm{mL}){ }^{5}$ Amphidinolides $\mathrm{F}(\mathbf{1})$ and $\mathrm{C}(\mathbf{2})$ have received a great interest from organic chemists, producing numerous synthetic approaches ${ }^{6}$ to these macrolides and finally culminating to two total syntheses of both amphidinolide $\mathrm{F}(\mathbf{1})$ and $\mathrm{C}(\mathbf{2}){ }^{7,8}$ We describe herein our achievement of the total synthesis of amphidinolide $\mathrm{F}(\mathbf{1})$.

From a retrosynthetic point of view, we initially planned to construct the THF ring using a $C$-glycosylation to form the C19-C20 bond. ${ }^{6 i, 6 r}$ Unfortunately, we found from model experiments that the diene framework was not compatible with the generated oxonium intermediate during this reaction.

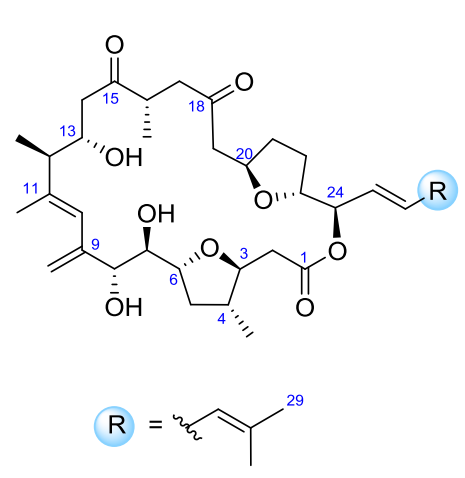

Amphidinolide F (1)
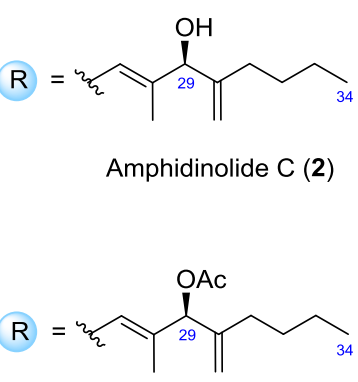

Amphidinolide C2 (3)

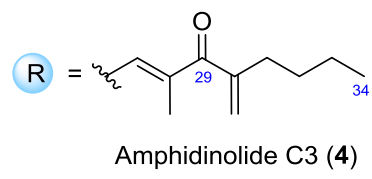

Figure 1. Structures of amphidinolide F, C, C2 and C3

Therefore, we changed this disconnection in order to perform the $C$-glycosylation reaction prior to the diene installation. Following this idea, we envisioned forging the macrolactone core with a sulfone condensation/desulfonylation sequence to connect $5(\mathrm{C} 18-\mathrm{C} 29)$ to $\mathbf{6}(\mathrm{C} 10-\mathrm{C} 17)$, and a Stille cross coupling to attach the sub-unit 7 (C1-C9), followed by a macrolactonisation (Scheme 1). Fragments 5, 6 and 7 could be synthesized through high diastereoselective reactions from chiral synthons easily accessible from the chiral pool or from well-known asymmetric reactions (e.g. Sharpless asymmetric epoxidation of allylic alcohol).

The synthesis of C18-C29 sub-unit $\mathbf{5}$ started from chiral lactone $\mathbf{8},{ }^{9}$ which was protected as a TBDPS (tertbutyldiphenylsilyl) ether and compound $\mathbf{9}$ was then subjected 

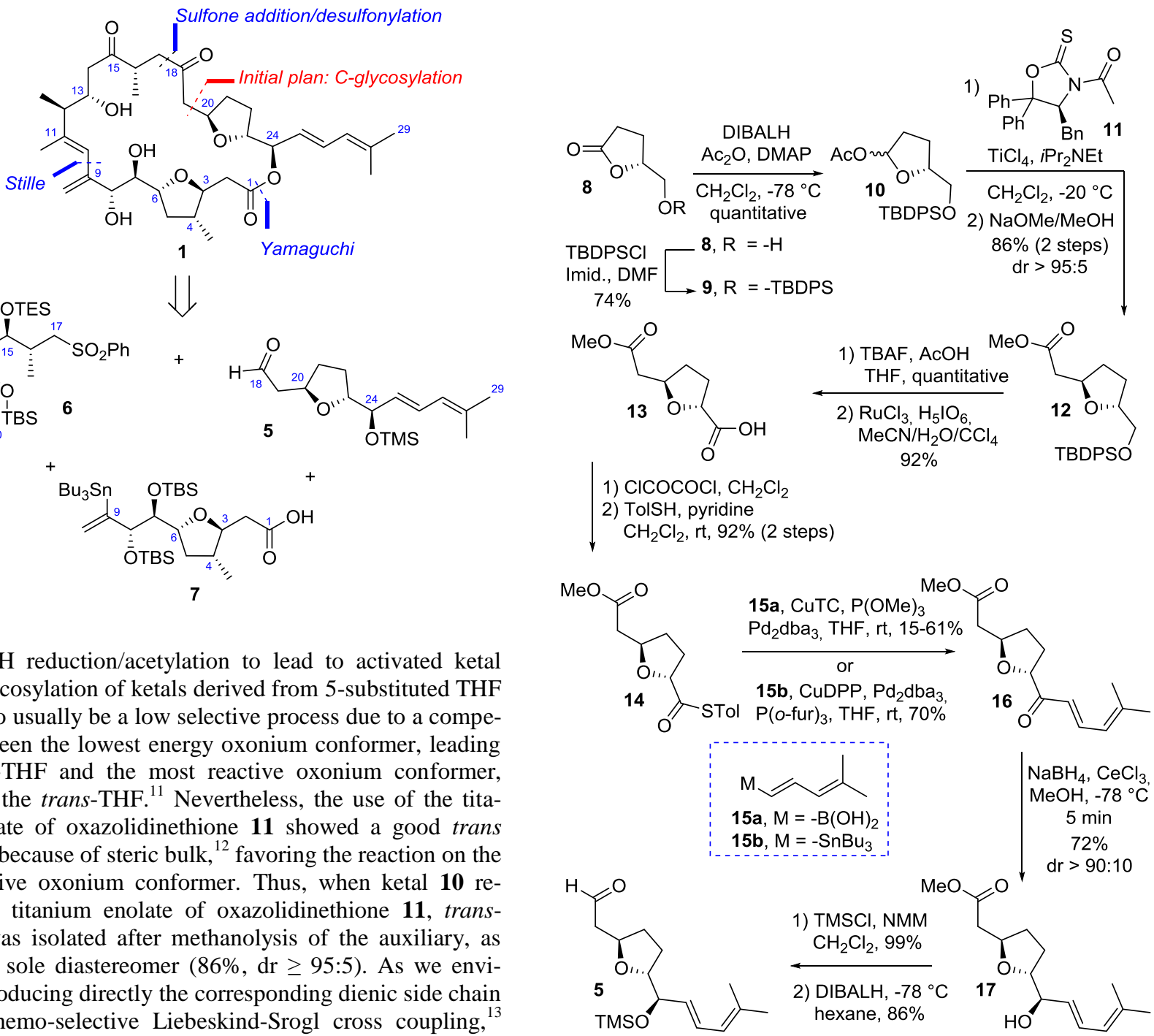

to DIBALH reduction/acetylation to lead to activated ketal 10. ${ }^{10} \mathrm{C}$-glycosylation of ketals derived from 5 -substituted THF is known to usually be a low selective process due to a competition between the lowest energy oxonium conformer, leading to the cis-THF and the most reactive oxonium conformer, leading to the trans-THF. ${ }^{11}$ Nevertheless, the use of the titanium enolate of oxazolidinethione $\mathbf{1 1}$ showed a good trans selectivity because of steric bulk, ${ }^{12}$ favoring the reaction on the most reactive oxonium conformer. Thus, when ketal $\mathbf{1 0}$ reacted with titanium enolate of oxazolidinethione 11, transTHF 12 was isolated after methanolysis of the auxiliary, as almost the sole diastereomer $(86 \%, \mathrm{dr} \geq 95: 5)$. As we envisioned introducing directly the corresponding dienic side chain using a chemo-selective Liebeskind-Srogl cross coupling, ${ }^{13}$ construction of a thioester moiety was required. Therefore the hydroxyl group was deprotected and oxidized into carboxylic acid 13 with in situ generation of ruthenium tetroxide. ${ }^{14} \mathrm{Car}-$ boxylic acid 13 was then transformed into thioester 14, through activation into an acyl chloride followed by reaction with thiocresol. As we initially carried out the cross coupling with the corresponding boronic acid derivative $15 \mathbf{a}^{6 \mathrm{r}}$ in presence of CuTC (copper thiophene carboxylate) and $\mathrm{Pd}_{2} \mathrm{dba}_{3} / \mathrm{P}(\mathrm{OMe})_{3}$, we observed non-reproducible results (15$61 \%$ ) in the formation of dienone $\mathbf{1 6}$, due to the instability of boronic acid 15a. However ketone 16 was obtained in a 70\% yield when more stable stannane $\mathbf{1 5} \mathbf{b}$ was used for the crosscoupling in conjunction with the use of CuDPP (copper diphenylphosphinate) and $\mathrm{Pd}_{2} \mathrm{dba}_{3} / \mathrm{P}(\mathrm{o}-\mathrm{fur})_{3}{ }^{15}$ Moreover, we also experienced that the synthesis of $\mathbf{1 5} \mathbf{b}$ is shorter and more practical than that of 15a (3 steps $v s$ 6). Reduction of dienone 16 using Luche conditions ${ }^{16}$ at $-78{ }^{\circ} \mathrm{C}$ gave us the syn product 17 in a polar Felkin-Anh fashion selectivity $(\mathrm{dr} \geq 90: 10){ }^{6 \mathrm{n}}$ Finally, the hydroxyl group was etherified with a fragile TMS protecting group, and the ester was converted into aldehyde $\mathbf{5}$ by using a selective reduction with DIBALH (Scheme 2).

In parallel, the synthesis of sub-unit $\mathrm{C} 10-\mathrm{C} 17$ (6) was conducted. The inherent symmetry of the C12-C16 segment could

be advantageously exploited by using ring-openings of epoxides with different nucleophiles. The use of an orthogonally protected hydroxyl group at C15 would selectively generate the ketone function in a later stage.. Thus, commercial alkyne 18 was selectively reduced to the corresponding $(Z)$-olefin with $\mathrm{Pd} / \mathrm{BaSO}_{4}$-quinoline and a Sharpless asymmetric epoxidation was performed using cumyl hydroperoxide to obtain epoxy alcohol $19(\mathrm{er}=93: 7)($ Scheme 3$){ }^{17}$ The protection/activation of the hydroxyl group as tosylate $\mathbf{2 0}$ allowed us to accomplish the ring-opening of the epoxide exclusively on its less hindered side with the help of a trimethylaluminium "ate" complex derived from TMS-acetylene in combination with $\mathrm{BF}_{3} \cdot \mathrm{OEt}_{2}$. ${ }^{18}$ The tosylate was then internally displaced by the generation of sodium alkoxide to give terminal epoxide $\mathbf{2 1}$. A second epoxide ring-opening was carried out with (Z)propenyl Grignard in presence of $\mathrm{CuI}$ giving (Z)-homo allyl alcohol 22. The two new stereogenic centers were installed by a $\mathrm{VO}(\mathrm{acac})_{2}$ directed-epoxidation and gave almost exclusively a single diastereomer $(\mathrm{dr}=43: 1){ }^{19}$ The protection of the hydroxyl as a TBS ether and methanolysis of TMS alkyne protecting group afforded compound 23. The last epoxide ring opening was performed with lithiated methylphenylsulfone in 
synergy with $\mathrm{BF}_{3} \cdot \mathrm{OEt}_{2}{ }^{20}$ The transformation was quantitative, but a mixture of regioisomers, in a separable 71:29 ratio, was obtained. Fortunately the lithium anion added preferentially on the less hindered face of the epoxide, and after an orthogonal protection with TES ether, compound $\mathbf{2 4}$ was obtained. Functionalization of the terminal alkyne present in compound $\mathbf{2 4}$ was troublesome. Negishi's zirconium catalyzed carboalumination $^{21}$ or stannylcupration followed by iodolysis ${ }^{22}$ did not allow us to set up the required functionalities. Thus, a reported four-step approach ${ }^{23}$ was successfully applied to our substrate giving rise to the accomplishment of the synthesis of fragment C10-C17 (6). A palladium mediated regio- and stereoselective trimethylsilyl-stannylation of alkyne $\mathbf{2 4}$ gave product $\mathbf{2 5}^{24}$ Then iodolysis of the stannane, followed by a substitution of iodide by dimethylcuprate, afforded compound $\mathbf{2 6}$. Final iodolysis of TMS with $\mathrm{NIS}^{25}$ in $\mathrm{MeCN} / \mathrm{CH}_{2} \mathrm{Cl}_{2}$ ended the sequence towards sub-unit 6 (Scheme 3).

\section{Scheme 3. Synthesis of the C10-C17 fragment (6).}
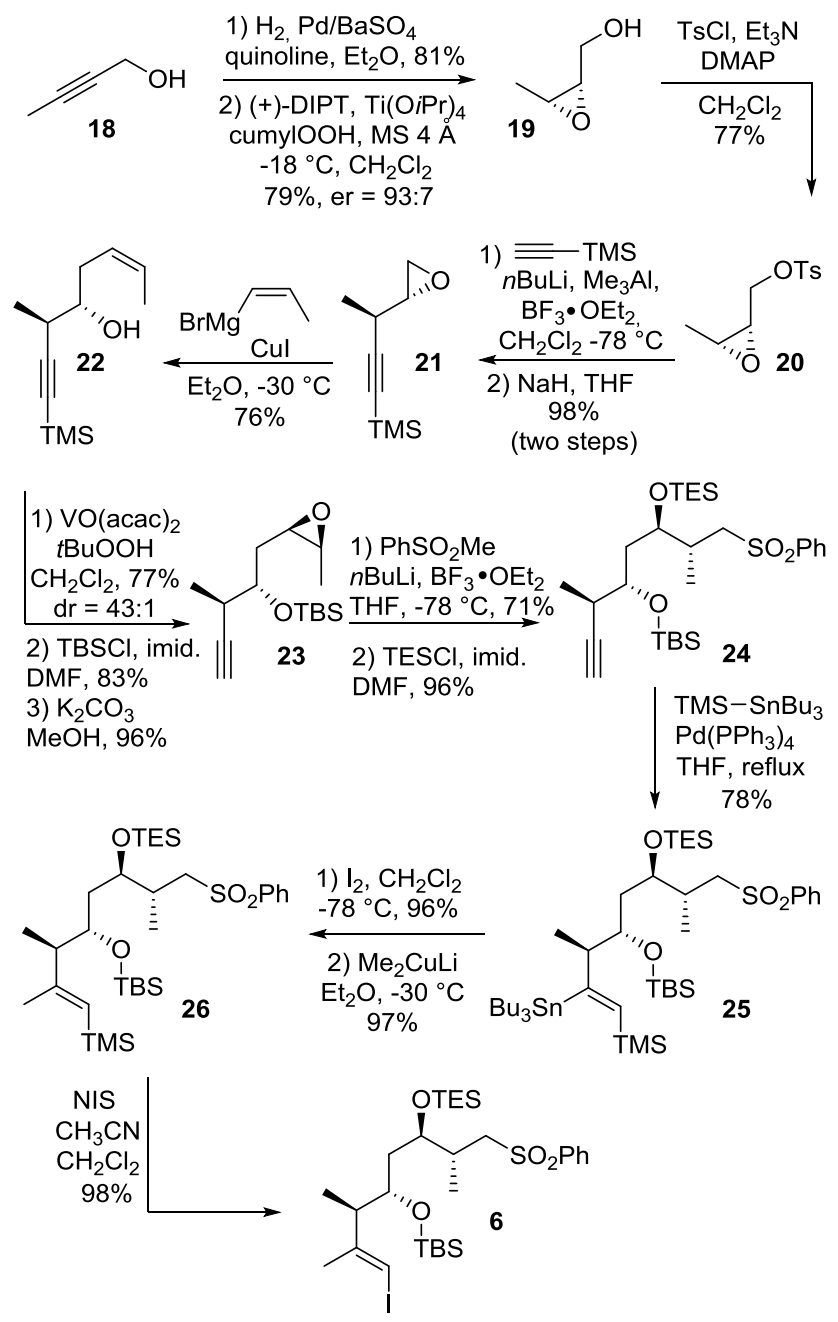

The linkage of subunits $\mathbf{5}$ and $\mathbf{6}$ was briefly studied. It was found that base, concentration and temperature were important parameters for the success of the sulfone condensation. Therefore, sulfone 6 was best deprotonated at $0{ }^{\circ} \mathrm{C}^{26}$ with LDA and aldehyde 5 was then added at $-78{ }^{\circ} \mathrm{C}$, followed by a slow warming to $0{ }^{\circ} \mathrm{C}$ delivering a complex mixture of four diastereomers. A two-step sequence including 2,6-lutidine buffered Dess-Martin oxidation of $\mathrm{C} 18$ alcohol and $\mathrm{SmI}_{2}$ mediated desulfonylation at $-78{ }^{\circ} \mathrm{C}$, afford compound 27 (Scheme 4, boxed).

The next step was the introduction of the last C1-C9 fragment. Sub-unit C1-C9 was synthesized using a strategy reported by us based on a vinylogous Mukaiyama aldol reaction followed by a $C$-glycosylation with an oxazolidinethione. ${ }^{6 i}$ Early studies indicated that the Stille cross-coupling with methyl ester $\mathbf{2 8}$ was effective using the copper mediated Liebeskind's protocol ${ }^{27}$ with a $45-55 \%$ yield range depending on the coupling partners. However, we later experienced some difficulties to cleanly saponify the corresponding methyl ester of such complex molecules. Thus, we decided to perform the Stille coupling between the free acid 7 , obtained by reaction of 28 with TMSOK, ${ }^{28}$ and vinyliodide 27 (Scheme 4). As we anticipated proto-demetallation issues between the free acid and the in situ generated vinyl copper species, we decided to treat first free acid 7 with $\mathrm{NaH}$ in DMF followed by addition of vinyl iodide $\mathbf{2 7}$ and other reagents needed. We were pleased to note that the cross-coupling was very effective, albeit that it resulted in a partial TMS deprotection. Therefore, treatment of the crude reaction mixture with dilute $\mathrm{HCl}$ selectively removed TMS ether and afforded, after purification, compound 29 (72\% yield). The macrolactonization took place using Yamaguchi reagent, ${ }^{29}$ affording compound $\mathbf{3 0}$ as a $3: 1$ mixture of at least two major conformers detectable by NMR. ${ }^{7,8}$ The TES group at $\mathrm{C} 15$ was selectively cleaved employing HF•pyridine in THF/pyridine ${ }^{30}$ giving a complex mixture of hydroxyketone and ketals in equilibrium. The probable presence of conformers makes this intermediate very difficult to characterize. Nevertheless, we can establish that the ketal form seems predominant due to the absence of the ketone absorption band $\left(v_{\mathrm{C}=\mathrm{O}}\right)$ at $1715 \mathrm{~cm}^{-1}$ in the infrared spectrum. The oxidation of hydroxyl at $\mathrm{C} 15$ was problematic, and Fürstner's conditions using TPAP (tetraproylammonium perruthenate) ${ }^{8}$ proved to be the most successful, giving compound $\mathbf{3 1}$ in good yield. Final deprotection of the three TBS groups was performed using $\mathrm{HF} \bullet$ pyridine in $\mathrm{THF} /$ pyridine. We noticed that $\mathrm{Et}_{3} \mathrm{~N} \cdot \mathrm{HF}$ reagent system, which was used in the previous total syntheses, ${ }^{7,8}$ produced significant degradation products in our hands (Scheme 4).

In conclusion, we synthesized amphidinolide $F(\mathbf{1})$ in 23 steps from the longest linear sequence and 47 total steps, which is a close result to Fürstner's total synthesis (21 steps, longest linear sequence; 39 total steps) and more favorable towards Carter's total synthesis (34 steps, longest linear sequence; 62 total steps). Characterization of our synthetic sample 1 was in accordance with previously reported total syntheses and natural product. ${ }^{31}$ Highlights of this synthesis include the stereoselective synthesis of both trans-THF rings using $C$ glycosylation reactions with the titanium enolate of bulky oxazolidinethiones, the exploitation of a inherent symmetry to build the C10-C19 fragment through iterative ring epoxide openings and a direct and versatile introduction of the dienic side chain via a Liebeskind-Srogl cross coupling. 

Scheme 4. Synthesis of amphidinolide F (1).

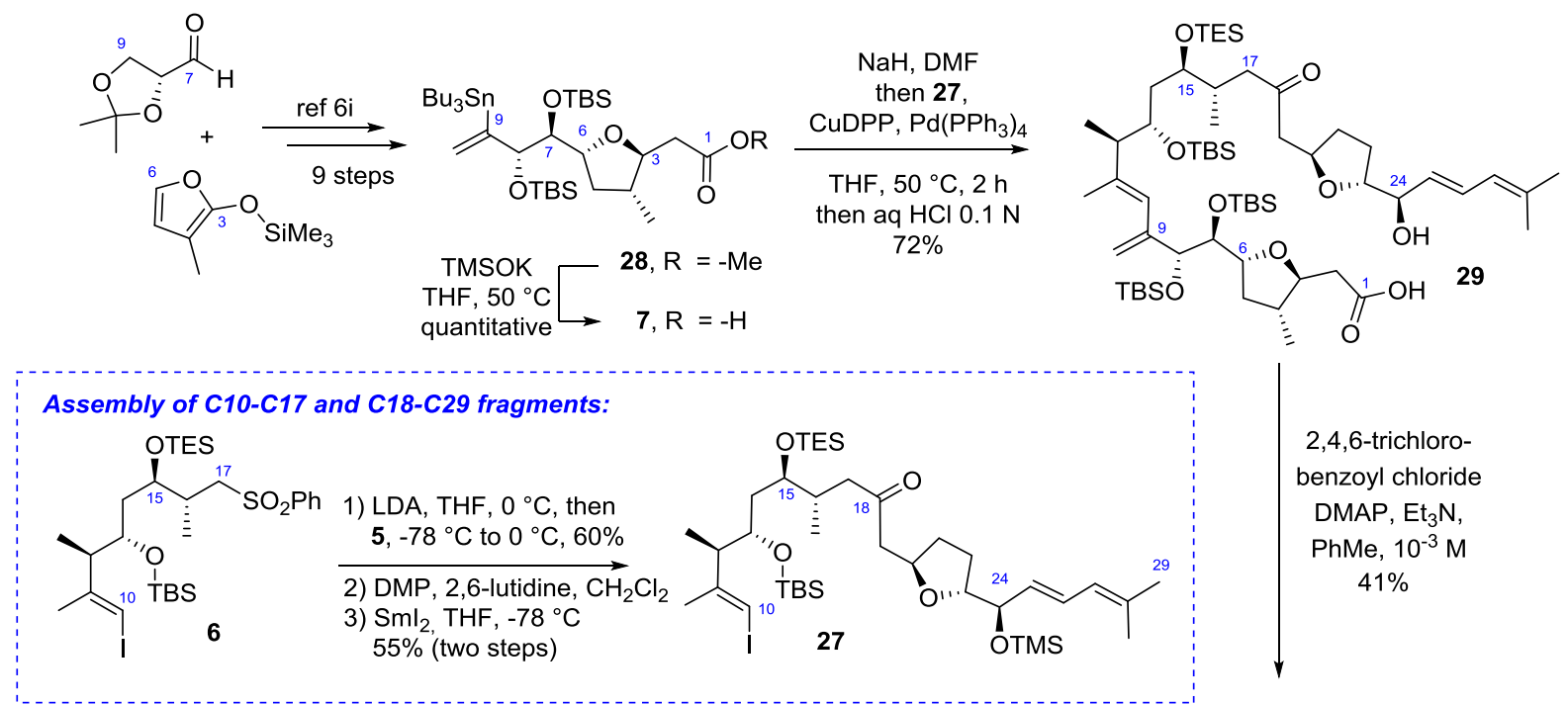

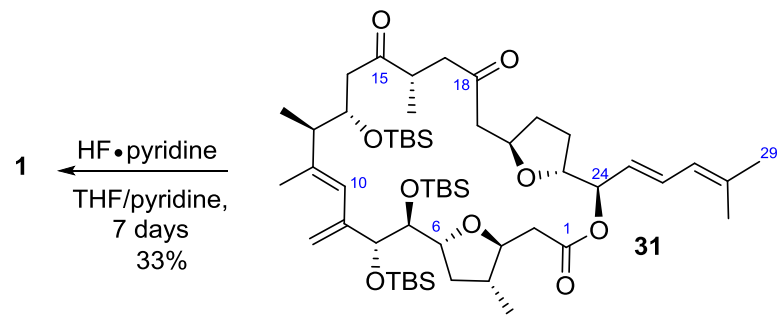

\section{AUTHOR INFORMATION}

\section{Corresponding Authors}

* E-mail: laurent.ferrie@u-psud.fr,

*E-mail: bruno.figadere@u-psud.fr

\section{ORCID}

Laurent Ferrié: 0000-0002-1171-205X

Johan Fenneteau : 0000-0003-41-3035

Bruno Figadère: 0000-0003-4226-8489

\section{Notes}

The authors declare no competing financial interest.

\section{ACKNOWLEDGMENT}

This work was supported by ANR through AMPHICTOT program (ANR-11-BS07-0028). We thank Karine Leblanc (BioCIS, Châtenay-Malabry) for HRMS analysis. We express our gratitude to ICSN and especially Jean-François Gallard (CNRS, Gif-surYvette, France) for experiments of our synthetic sample of amphidinolide $\mathrm{F}$ on a $800 \mathrm{MHz}$ NMR spectrometer.

\section{REFERENCES}

(1) (a) Kobayashi, J.; Ishibashi, M. Chem. Rev. 1993, 93, 17531769. (b) Kobayashi, J.; Tsuda, M. Nat. Prod. Rep. 2004, 21, 77-93. (c) Kobayashi, J.; Kubota, T. J. Nat. Prod. 2007, 70, 451-460. d) Kobayashi, J. J. Antibiot. 2008, 61, 271-284.

(2) Kobayashi, J.; Tsuda, M.; Ishibashi, M.; Shigemori, H.; Yamasu, T.; Hirota, H.; Sasaki, T. J. Antibiot. 1991, 44, 1259-261.

(3) (a) Kobayashi, J.; Ishibashi, M.; Wälchli, M. R.; Nakamura, H.; Hirata, Y.; Sasaki, T.; Ohizumi, Y. J. Am. Chem. Soc. 1988, 110 490-494. (b) Kubota, T.; Tsuda, M.; Kobayashi, J. Org. Lett. 2001, 3, $1363-1366$.
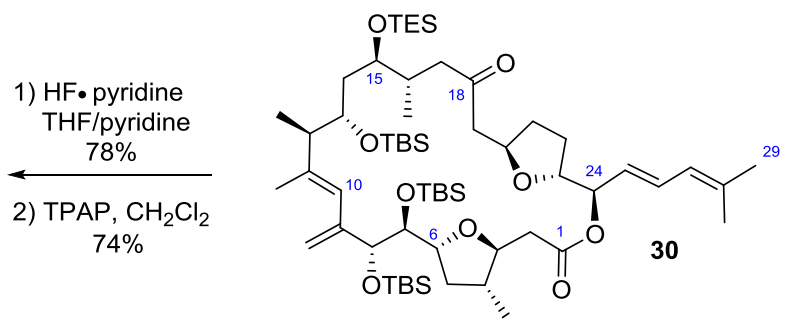

(4) Kubota, T.; Sakuma, Y.; Tsuda, M.; Kobayashi, J. Mar. Drugs 2004, 2, 83-87.

(5) Kubota, T.; Suzuki, A.; Yamada, M.; Baba, S.; Kobayashi, J., Heterocycles 2010, 82, 333-338.

(6) (a) Ishiyama, H.; Ishibashi, M.; Kobayashi, J. Chem. Pharm. Bull. 1996, 44, 1819-1822. (b) Kubota, T.; Tsuda, M.; Kobayashi, J., Tetrahedron 2003, 59, 1613-1625. (c) Shotwell, J. B.; Roush, W. R., Org. Lett. 2004, 12, 3865-3868. (d) Mohapatra, D. K.; Rahaman, M., Chorghade, S.; Gurjar, M. K., Synlett, 2007, 567-570. (e) Bates, R. H.; Shotwell, J. B.; Roush, W. R. Org. Lett. 2008, 9, 4343-4346. (f) Armstrong, A.; Pyrkotis, C. Tetrahedron Lett. 2009, 50, 3325-3328. (g) Mohapatra, D. K.; Dasari, P.; Rahaman, H.; Pal, R. Tetrahedron Lett. 2009, 50, 6276-6279. (h) Paudyal, M. P.; Rath, N. P.; Spilling, C. D. Org. Lett. 2010, 12, 2954-2957. (i) Ferrié, L.; Figadère, B. Org. Lett. 2010, 12, 4976-4979. (j) Roy, S.; Spilling, C. D. Org. Lett. 2010, 12, 5326-5329. (k) Morra, N. A.; Pagenkopf, B. L. Org. Lett. 2011, 13, 572-575. (1) Wu, D.; Forsyth, C. J. Org. Lett. 2013, 15, 1178-1181. (m) Clark, J. S.; Yang, G.; Osnowski, A. P. Org. Lett. 2013, 15, 1460-1463. (n) Clark, J. S.; Yang, G.; Osnowski, A. P. Org. Lett. 2013, 15, 1464-1467. (o) Morra, N. A.; Pagenkopf, B. L. Tetrahedron 2013, 69, 8632-8644. (p) Morra, N. A.; Pagenkopf, B. L. Eur. J. Org. Chem. 2013, 756-760. (q) Delcamp, J. H.; Gormisky, P. E.; White, M. C. J. Am. Chem. Soc. 2013, 135, 8460-8463. (r) Fenneteau, J.; Vallerotto, S.; Ferrié, L.; Figadère, B. Tetrahedron Lett. 2015, 56, $3758-3761$

(7) (a) Mahapatra, S.; Carter, R. G. Angew. Chem. 2012, 124, 8072-8075; Angew. Chem. Int. Ed. 2012, 51, 7948-7951; (b) Mahapatra, S.; Carter, R. G. J. Am. Chem. Soc. 2013, 135, 10792 10803.

(8) (a) Valot, G.; Regens, C. S.; O’Malley, D. P.; Godineau, E.; Takikawa, H.; Fürstner, A. Angew. Chem., 2013, 125, 9713-9717; Angew. Chem. Int. Ed., 2013, 52, 9534-9538. (b) Valot, G.; D. Mailhol, D.; Regens, C. S.; O’Malley, D. P.; Godineau, E.; Takikawa, H.; Philipps P.; Fürstner, A. Chem. Eur. J. 2015, 21, 2398 2408 . 
(9) Commercially available or prepared from $(R)$-glutamic acid. See: (a) Boukouvalas, J. in Encyclopedia of Reagents for Organic Synthesis, John Wiley \& Sons, Ltd, 2001, Dihydro-5(hydroxymethyl)-2(3H)-furanone; (b) Shiro, Y.; Kato, K.; Fuji, M.; Ida, Y.; Akita, H. Tetrahedron 2006, 62, 8687-8695. (c) Cai, X.; Chorghade, M. S.; Fura, A.; Grewal, G. S.; Jauregui, K. A.; Lounsbury, H. A.; Scannell, R. T.; Yeh, C. G.; Yong, M. A.; Yu, S. Org. Proc. Res. Dev. 1999, 3, 73-76.

(10) Kopecky, D. J.; Rychnovsky, S. D. J. Org. Chem. 2000, 65 191-198.

(11) Schmitt, A.; Reissig, H. U. Eur. J. Org. Chem., 2000, 23, 3893-3901.

(12) (a) Jalce, G.; Seck, M.; Franck, X.; Hocquemiller, R.; Figadère, B. J. Org. Chem. 2004, 69, 3240. (b) Jalce, G.; Franck, X.; SeonMeniel, B,; Hocquemiller, R.; Figadère, B. Tetrahedron Lett. 2006, 47, 5905-5908. (c) Jalce, G.; Franck, X.; Figadère, B. Eur. J. Org. Chem. 2009, 3, 378-386.

(13) Carlsen, P. H. J.; Katsuki, T.; Martin, V. S.; Sharpless, K. B. J. Org. Chem. 1981, 46, 3936-3938.

(14) (a) Liebeskind, L. S.; Srogl, J. J. Am. Chem. Soc. 2000, 122, 11260-11261. (b) Yang, H.; Li, H.; Wittenberg, R.; Egi, M.; Huang, W.; Liebeskind, L. S. J. Am. Chem. Soc. 2007, 129, 1132-1140. (c) Prokopcová, H.; Kappe, C. O. Angew. Chem. 2009, 121, 2312-2322; Angew. Chem. Int. Ed. 2009, 48, 2276-2286.

(15) (a) Wittenberg, R.; Srogl, J.; Egi, M.; Liebeskind, L. S. Org. Lett. 2003, 5, 3033-3035. (b) Li, H.; Yang, H.; Liebeskind, L. S. Org. Lett. 2008, 10, 4375-4378.

(16) Luche, J. L. J. Am. Chem. Soc. 1978, 100, 2226-2227.

(17) Gao, Y.; Klunder, J. M.; Hanson, R. M.; Masamune, H.; Ko, S. Y.; Sharpless, K. B. J. Am. Chem. Soc. 1987, 109, 5765-5780.

(18) (a) Alexakis, A.; Jachiet, D. Tetrahedron 1989, 45, 61976202. (b) Skrydstrup, T.; Bénéchie, M.; Khuong-Huu, F. Tetrahedron Lett. 1990, 31, 7145-7148.

(19) Mihelich, E. D.; Daniels, K.; Eickhoff, D. J. J. Am. Chem. Soc. 1981, 103, 7690-7692.

(20) (a) Achmatowicz, B.; Marczak, S.; J. Wicha, J. J. Chem. Soc. Chem. Commun. 1987, 1226-1228. (b) Zhu, J.; Ma, D. Angew. Chem. 2003, 115, 5506-5509; Angew. Chem. Int. Ed. 2003, 42, 5348-5351. (c) Ley, S. V.; Tackett, M. N.; Maddess, M. L.; Anderson, J. C.; Brennan, P. E.; Cappi, M. W.; Heer, J. P.; Helgen, C.; Kori, M.; Kouklovsky, C.; Marsden, MS. P.; Norman, J.; Osborn, D. P.;
Palomero, M. A.; Pavey, J. B. J.; Pinel, C.; Robinson, L. A.; Schnaubelt, J.; Scott, J. S.; Spilling, C. D.; Watanabe, H.; Wesson, K. E.; Willis, M. C. Chem. Eur. J. 2009, 15, 2874-2914.

(21) (a) Van Horn, D. E.; Negishi, E. J. Am. Chem. Soc. 1978, 100, 2252-2254. (b) Rand, C. L.; Van Horn, D. E.; Moore, M. W.; Negishi, E. J. Org. Chem. 1981, 46, 4093-4096. (c) Wipf, P.; Lim, S. Angew. Chem. 1993, 105, 1095-1097; Angew. Chem. Int. Ed. 1993, $32,1068-1071$.

(22) (a) Smith, A. B. ; Minbiole, K. P.; Verhoest, P. R.; Schelhaas, M. J. Am. Chem. Soc. 2001, 123, 10942-10953. (b) Gopalarathnam, A; Nelson, S. G. Org. Lett. 2006, 8, 7-10.

23) (a) Cid, B.; Pattenden, G. Synlett 1998, 540-542. (b) Williams, D. R.; Walsh, M. J.; Miller, N. A. J. Am. Chem. Soc. 2009, 131, 9038-9045.

(24) (a) Mitchell, T. N.; Killing, H.; Dicke, R.; Wickenkamp, R. J. Chem. Soc. Chem. Comm. 1985, 354-355. (b) Chenard, B. L.; Laganis, E. D.; Davidson, F.; RajanBabu, T. V. J. Org. Chem. 1985, 50, 3666-3667. (c) Chenard, B. L.; Van Zyl, C. M.; J. Org. Chem. 1986, 51, 3561-3566. (d) Mitchell, T. N.; Wickenkamp, R.; Amamria, A.; Dicke, R.; Schneider, U. J. Org. Chem. 1987, 52, 48684874

(25) Stamos, D. P.; Taylor, A. G.; Kishi, Y. Tetrahedron Lett. 1996, 37, 8647-8650.

(26) Jeong, J. W.; Woo, B. Y.; Ha, D.-C.; No, Z. Synlett 2003, 393-395.

(27) (a) Allred, G. D.; Liebeskind, L. S. J. Am. Chem. Soc. 1996, 118, 2748-2749. (b) Fürstner, A.; Funel, J.-A.; Tremblay, M.; Bouchez, L. C.; Nevado, C.; Waser, M.; Ackerstaff, J.; Stimson, C. C. Chem. Commun. 2008, 25, 2873-2875.

(28) Laganis, E. D.; Chenard, B. L. Tetrahedron Lett. 1984, 25, $5831-5834$

(29) (a) Inanaga, J.; Hirata, K.; Saeki, H.; Katsuki, T.; Yamaguchi, M. Bull. Chem. Soc. Jpn. 1979, 52, 1989-1993. (b) Hikota, M.; Sakurai, Y.; Horita, K.; Yonemitsu, O. Tetrahedron Lett. 1990, 31, 63676370 .

(30) (a) Crouch, R. D. Tetrahedron 2013, 69, 2383-2417. (b) Nelson, T. D.; Crouch, R. D. Synthesis 1996, 1031-1069.

(31) See Supplementary Information for ${ }^{1} \mathrm{H}$ and ${ }^{13} \mathrm{C}$ comparison table between natural and synthetic sample of $\mathbf{1}$ : (ESI Tables 1 and 2). 